\title{
GAS EXCHANGE IN YOUNG PLANTS OF THE SPECIES Tabebuia aurea EXPOSED TO CONDITIONS OF INDUCED WATER STRESS
}

\author{
TROCAS GASOSAS EM PLANTAS JOVENS DE Tabebuia aurea SUBMETIDAS A \\ CONDIÇÕES DE ESTRESSE HÍDRICO INDUZIDO
}

\author{
Ademir Kleber Morbeck de OLIVEIRA ${ }^{1}$; Sônia Cristina Juliano GUALTIERI ${ }^{2}$ \\ 1. Professor, Doutor, Universidade Anhanguera-Uniderp, Campo Grande, MS, Brasil; Professora, \\ Doutora, Universidade Federal de São Carlos, São Carlos, SP, Brasil. \\ akmorbeckoliveira@gmail.com
}

\begin{abstract}
The paratudo, Tabebuia aurea, is a common Brazilian tree from the Pantanal wetland from Miranda, Mato Grosso do Sul, an area with hydric seasonality. To evaluate the effects of water stress on $\mathrm{CO}_{2}$ exchange, ten-month-old $T$. aurea seedlings cultivated in planting bags were subjected to water stress by suppressing irrigation for 23 days. Stomatal conductance, transpiration rate, and photosynthetic rate were measured during the stress and recovery period, totaling 28 days, using an infrared portable analyzer. After 23 days without irrigation, the transpiration, stomatal conductance, and net photosynthesis rates in leaflets were zero, while the leaflets water potential reached -2.6 MPa. After this point, daily irrigation was resumed, and the values of the measured variables recovered to the initial levels after 96 hours (transpiration rate from 2.0 to 2.6 mmol m$~^{-2} \mathrm{~s}^{-1}$; stomatal conductance rate from 0.12 to $0.18 \mathrm{~mol} \mathrm{~m}^{-2} \mathrm{~s}^{-1}$ and photosynthesis rate from 8.1 to 9.5 $\left.\mu \mathrm{mol} \mathrm{m} \mathrm{m}^{-2} \mathrm{~s}^{-1}\right)$. Furthermore, the hydric potential values were similar to those observed at the beginning of the experiment $(-0.5 \mathrm{MPa})$. The results showed that $T$. aurea has tolerance to drought, allowing their survival in areas subjected to periodic water stress.
\end{abstract}

KEYWORDS: Hydric deficit. Photosynthesis. Stomatal conductance. 'Paratudo'.

\section{INTRODUCTION}

Water is a limiting factor for plant development, and environmental studies of tree species under conditions of water stress are fundamentally important; this deficit leads to a reduction in photosynthetic capacity and plant growth rates, in which each species demonstrating different behavior when in hydric deficit (CHAVES et al., 2002; GALLÉ et al., 2007; LARCHER, 2010). Morais et al. (2003) and $\mathrm{Xu}$ and Zou (2008) wrote that lower photosynthetic activity can also result from stomatal responses to soil hydric deficit, among other factors.

According to Martinez et al. (2007) and Rahman and Hasegawa (2012), the stomatal closure causes a decrease in the partial $\mathrm{CO}_{2}$ pressure, limiting transpiration, an important mechanism to prevent water loss under stress conditions in addition to limiting the chloroplast $\mathrm{CO}_{2}$ fixation capacity.

The plants, in which hydric restriction is common, stomatal closure during periods of increased water loss and the reduction of internal cellular hydric potential through solute accumulation, favoring the soil water absorption (JALEEL et al., 2009). According to Taiz and
Zeiger (2010), the water potential to occur closing of stomata is variable; for some species a water potential of -1.0 to $-2.0 \mathrm{MPa}$ can lead to virtually zero transpiration and $\mathrm{CO}_{2}$ assimilation rates.

In order to survive in environments under water stress many species employ intracellular solute accumulation to adjust to lower water availability, which allows maintenance of cell turgor, stomatal opening and, consequently, photosynthesis rates by determined periods (SAITO; TERASHIMA, 2004; RAHMAN; HASEGAWA, 2012).

Oliveira et al. (2012) have reported that seedling survival in savannas and dry forests is associated with the duration of water stress and flora has suffered from strong selective pressures, leading to an evolution of mechanisms that allow survival under water stress.

There are different biomes subject to periodic droughts and between them, Pantanal Matogrossense, where drought conditions occur during part of the year, being this factor directly related to evapotranspiration that occurs more strongly than precipitation (SCREMIN-DIAS et al., 2011). In this region, many formations are almost exclusively populated by a single species which often dominate extensive areas, such as Paratudal, 
Gas exchange in young plants...

as a single dominant tree species, the paratudo Tabebuia aurea (Silva Manso) Benth. \& Hook. f. ex S. Moore (SOARES; OLIVEIRA, 2009).

Considering the importance of studying native species, the objective of this study was to determine the tolerance level of $T$. aurea to drought on Pantanal of Mato Grosso, evaluating gas exchange mechanisms and how it oscillates under periodic water stress.

\section{MATERIAL AND METHODS}

\section{Seed collection, germination and seedling formation}

T. aurea fruits were harvested from trees $(+$ 30) situated in the Miranda River sub-basin (Upper Paraguay river basin) in Pantanal de Miranda, municipality of Corumbá, Mato Grosso do Sul, specifically in a region known as Passo do Lontra

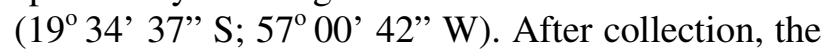
fruits were placed into paper bags and transported to the Anhanguera-Uniderp University, and kept at 25 ${ }^{\circ} \mathrm{C}$ in the Vegetal Ecophysiology Laboratory.

The seeds inside the dry fruits with natural dehiscence were collected and germinated in petri dishes containing moistened filter paper and kept on laboratory shelves under environmental temperatures $\left(20-25^{\circ} \mathrm{C}\right)$.

After germination, the seedlings were transferred to trays containing vermiculite and irrigated daily with distilled water. When they reached a height of $7 \mathrm{~cm}$ above the soil (11 days after germination), the seedlings were transplanted to planting bags (black plastic seedling bags, $7 \mathrm{~kg}$ capacity) containing substrate. The substrate used in the experiment was collected in Cerrado areas, between 0 and $20 \mathrm{~cm}$ in depth and classified as Eutrodox (Canchim unit) with a sandy texture.

Each bag received a unique seedling and was maintained in a greenhouse (Doubly Poly $\mathrm{Pad} /$ Fan greenhouse model) covered with plastic film with $35 \%$ retention of brightness (light intensity of $65 \%$ in the greenhouse when compared to $100 \%$ in full daylight). The minimum, maximum, and average temperature were respectively, $15 \pm 2$ ${ }^{\circ} \mathrm{C}, 25 \pm 2{ }^{\circ} \mathrm{C}$ and $20^{\circ} \mathrm{C}$; the relative humidity, $60 \pm$ $10 \%$, maintained through of nebulizers. The two parameters were evaluated by means of a portable thermo-hygrometer (Minipa, MT-242).

\section{Water stress}

Ten months after emergence, parts of plants were subjected to conditions of water stress simulated by suppression of irrigation (stopping the watering). To measure leaflets gas exchange, four
OLIVEIRA, A. K. M.; GUALTIERI, S. C. J.

individuals from each group randomly chosen were used (15 control plants and 15 plants under stress). The measurements were always performed on the first leaflets emitted from each plant (older leaflets).

The experiment was completely randomized with two treatments (1 - water suppression; 2 - daily irrigation until soil saturation).

\section{Response curve to different light intensities and light compensation point}

The photosynthesis was evaluated with a Hoddesdon model LCA-2 $\mathrm{CO}_{2}$ infrared portable analyzer (IRGA, Analytical Development Company - ADC) connected to an air supply unit (ADC ASU; $\mathrm{MF}$ ), processor and data storage unit (DL-2), with an air reference of $38-40 \%$ adjusted for relative humidity.

Once established the maximum photosynthesis rate through the gradual increase of light intensity, utilizing IRGA, the response curve was elaborated to different light intensities and the light compensation point obtained, following procedures of Motta et al. (2009), where the maximum photosynthetic capacity characterizes the behavior of plants in relation to the use of photosynthetically active radiation. In general terms, the greater the value of the maximum photosynthetic capacity means the greater photosynthetic gain. The determination of the saturation intensity was obtained before the start of the irrigation suspension, with evaluation conducted in the morning, approximately at 7:30 A.M.

\section{Photosynthetic measures}

Daily measurements of $\mathrm{P}_{\mathrm{N}}$ (net photosynthesis, $\mu \mathrm{mol} \mathrm{m}^{-2} \mathrm{~s}^{-1}$ ) were taken until photosynthesis reached a constant level using the IRGA. When placed in the chamber and submitted to artificial light, the leaflets showed gradual increase in photosynthetic rates and after 10 seconds, approximately, the value became stable with evaluations conducted in the morning, usually after 7:30 A.M. Then, measurements of $E$ (transpiration, mmol $\mathrm{m}^{-2} \mathrm{~s}^{-1}$ ) and $\mathrm{G}_{\mathrm{s}}$ (stomatal conductance related to water steam, mol m $\mathrm{m}^{-2} \mathrm{~s}^{-1}$ ) were carried out using primary leaflets that remained in the chamber for 10 and 20 seconds. A record was registered every three seconds, approximately, totaling three per leaflet and attempts were made to use the same pairs of leaflets for each evaluation. All mean values were used to build the figures.

The measurements were conducted at a light intensity of $1.200 \mu \mathrm{mol} \mathrm{m} \mathrm{m}^{-2} \mathrm{~s}^{-1}$ produced by an overhead light. This value was defined as the most 
appropriate after the elaboration of the response curve to different light intensities and light compensation point. A bowl containing water was placed between the light source and plants to avoid excessive heating of the leaflets. The measurements were carried out for 28 days, and irrigation occurred on day 23 .

\section{Leaflets water potential}

The leaflets water potential $\left(\Psi_{\mathrm{w}}\right)$ was obtained using the Scholander pressure chamber (PMS-1000, EUA) using four plants, an adult leaflet per plant (four repetitions). Evaluations were conducted in the morning, usually after 7:30 A.M. The measurements were carried out for 28 days, and irrigation occurred on day 23.

\section{RESULTS AND DISCUSSION}

\section{Leaflets water potential}

Water potential values of the leaflets of the first nine days were between -0.4 and $-0.6 \mathrm{MPa}$ (Figure 1). From day 11 onward, the hydric potential decreased from -1.0 MPa until reaching 2.6 $\mathrm{MPa}$ on day 23 , when net photosynthesis was $0.0 \mu \mathrm{mol} \mathrm{m} \mathrm{m}^{-2} \mathrm{~s}^{-1}$. This was the hydric potential value $(-2.6 \mathrm{MPa})$ that limited photosynthesis for this species at ten months of age. After this period, irrigation was resumed. On day 24, the hydric potential value reached $-1.2 \mathrm{MPa}$, but returned to the initial value on day 25 (-0.6 MPa) (Figure 1).

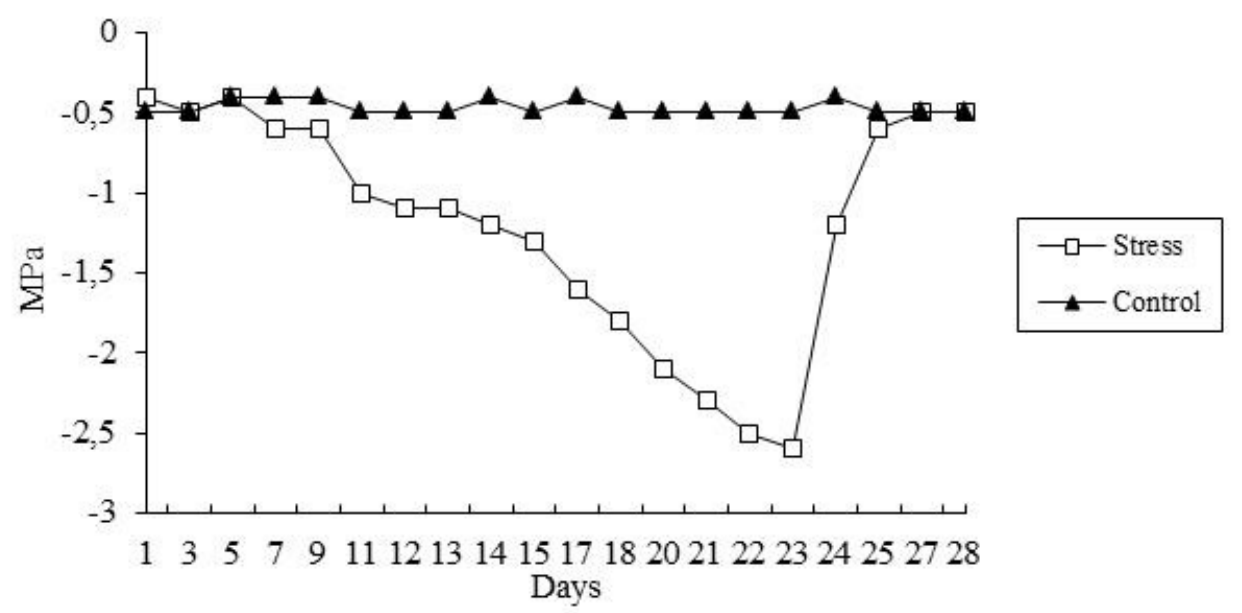

Figure 1. Leaflets water potential (MPa) in the two experimental groups (stress and control) of Tabebuia aurea potted plants.

This response (leaflets water potential, decrease) was expected, once Mansur and Barbosa (2000) studied Caatinga species, and found that leaflets water potential is reduced by decreasing the availability of water in the soil, causing loss of turgor and stomatal closure.

Oliveira et al. (2011) studied individuals of T. aurea under stress, and found similar behavior for five-month-old $T$. aurea, with values between 0.4 and $-0.6 \mathrm{MPa}$ for the control plants, and until -2.6 $\mathrm{MPa}$ for stressed plants. However, plants with higher growth time (this study) take longer to reach the lowest value of MPa (23 days), while young plants take 14 days, indicating that the longer the growth, the greater the resistance to water stress is. The recovery process is rapid, both for younger or older individuals, being less than 48 hours.

The minimum values for leaflets water potential found for $T$. aurea are higher than those reported by Rocha and Moraes (1997), who have tested young Stryphnodendron adstringens (Mart.) Coville plants $(-2.7 \mathrm{MPa})$ found in Cerrado. Although T. aurea can also be found in different areas of Cerrado, the present samples were collected from Pantanal, which presents different environmental conditions from those found in savanna biome. This geographical difference might explain the higher value found in the present study when compared to other species of this biome.

According to Larcher (2010), plants found in different ecosystems may present differences in their genotype expression caused by environmental influences (plasticity), allowing the species to adapt to different environments. Wang et al. (2011) studied Leymus chinensis (Trin.) Tzvelev along large-scale longitudinal gradient in Northeast China, and also observed these adaptations. 
Gas exchange in young plants...

Some authors, such as Larcher (2010), claim that mesophytic plants from tropical forests with water potentials between -1.5 and $-4.0 \mathrm{MPa}$ can reach zero photosynthesis rates, indicating that $T$. aurea exhibits mesophytic plant characteristics in response to water stress; also, the slow decrease in hydric potential and in other parameters evaluated (transpiration, stomatal conductance, and photosynthesis).

However, not all species may present this behavior. Souza et al. (2010) investigated four species (Inga sp., Cinnamomum zeylanicum Blume,
OLIVEIRA, A. K. M.; GUALTIERI, S. C. J.

Brosimum guianensis Aubl. and Tapirira guianensis Aubl.) during drought (7 days), and observed a reduction of $\Psi_{\mathrm{w}}$ in all species studied, except for $C$. zeylanicum.

\section{Light compensation point}

The light compensation point at which the level of illumination at which photosynthetic fixation of carbon dioxide matches respiratory loss was $65.7 \mu \mathrm{mol} \mathrm{m}^{-2} \mathrm{~s}^{-1}$ and the maximum photosynthesis rate obtained for T. aurea was 11.7 $\mu \mathrm{mol} \mathrm{m} \mathrm{s}^{-1}$ (Figure 2).

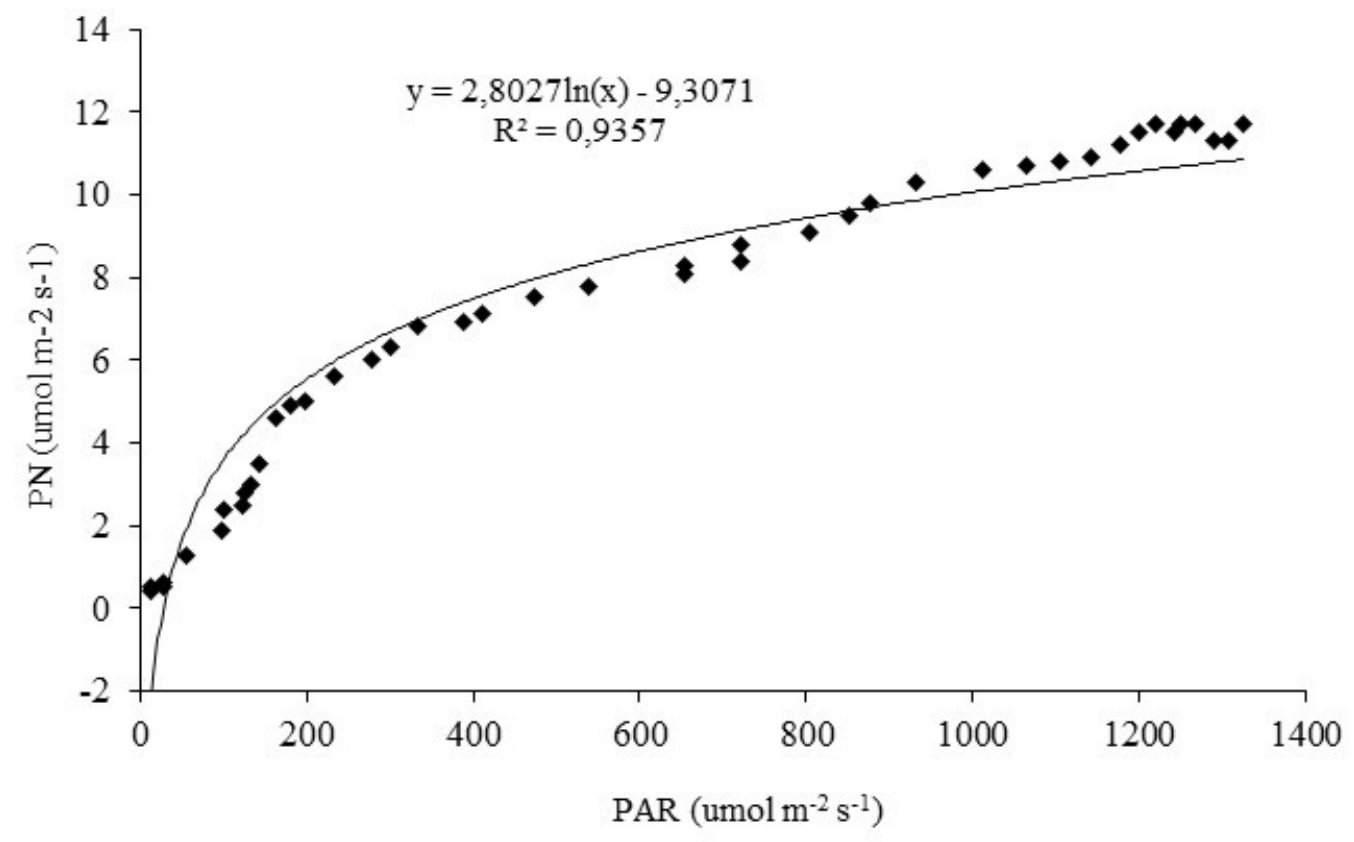

Figure 2. Net photosynthesis rate (PN, $\mu \mathrm{mol} \mathrm{m} \mathrm{s}^{-2}$ ) as a function of photosynthetically active radiation (PAR $\left.\mu \mathrm{mol} \mathrm{m} \mathrm{m}^{-1}\right)$ in hydrated Tabebuia aurea potted plants.

The value for light compensation point was higher than that observed by Rocha and Moraes (1997) for six-month-old S. adstringens $(59 \mu \mathrm{mol} \mathrm{m}$ $\left.{ }^{2} \mathrm{~s}^{-1}\right)$, Calbo and Moraes (2000) for four-month-old Euterpe oleracea Mart. palm trees $\left(18.1 \mu \mathrm{mol} \mathrm{m}^{-2} \mathrm{~s}\right.$ $\left.{ }^{1}\right)$, and Mendéz et al. (2012) for palm interspecific hybrids U1914 (Elaeis oleifera H.B.K. Cortes versus $E$. guianeensis Jacq.) in water deficit ( -0.042 $\mathrm{MPa}), 13.8 \mu \mathrm{mol}$ photons $\mathrm{m}^{-2} \mathrm{~s}^{-1}$. The data presented by Oliveira et al (2011) for five-month-old T. aurea $\left(53.4 \mu \mathrm{mol} \mathrm{m} \mathrm{m}^{-2} \mathrm{~s}^{-1}\right)$ indicate that the PLC of the species increases as the plant grows older.

The maximum photosynthesis rate obtained for $T$. aurea was higher than that found by Calbo and Moraes (2000) for E. oleracea $\left(4.2 \mu \mathrm{mol} \mathrm{m}^{-2} \mathrm{~s}^{-}\right.$ $\left.{ }^{1}\right)$ and Oliveira et al. (2011) for five-month-old $T$. aurea $\left(9.9 \mu \mathrm{mol} \mathrm{m} \mathrm{m}^{-2} \mathrm{~s}^{-1}\right)$, demonstrating that the maximum photosynthesis rate increases as individuals get older. Nonetheless, this rate was lower than that observed by Rocha and Moraes (1997) for S. adstringens $\left(12.9 \mu \mathrm{mol} \mathrm{m}^{-2} \mathrm{~s}^{-1}\right)$, and by Mendéz et al. (2012) for palm interspecific hybrids U1937 in water deficit (-0.042 MPa), $12.7 \mu \mathrm{mol} \mathrm{m}^{-2}$ $\mathrm{s}^{-1}$.

As reported before by Lawlor and Cornic (2002), the foliar photosynthetic rate of higher plants decreases with the reduction in the relative water content and leaflets water potential. However, there is a great diversity in the behavior of species from areas under temporary water stress. For example, Franco et al. (2005) studied 11 tree species from the Neotropical savannas (Cerrado) and found values ranging from $16.3 \mu \mathrm{mol} \mathrm{m} \mathrm{m}^{-2} \mathrm{~s}^{-1}$ (Schefflera macrocarpa Cham. \& Schltdl. Frodin) to $8.8 \mu \mathrm{mol}$ $\mathrm{m}^{-2} \mathrm{~s}^{-1}$ (Vochysia elliptica Mart.), demonstrating again different behavioral strategies. 
Normally, photosynthesis rate raises in response to increases in light up to approximately $25 \%$ of total sunlight, and are later limited by the availability of reducing power - NADPH; the photosynthesis is not limited when the saturating light intensity is reached. This only occurs when there is less carbon fixation as a result of a decrease in carbon dioxide supply to carboxylation sites (AKINCI; LÖSEL 2012).

The photosynthetic capacity is an intrinsic characteristic of each species, and the photosynthesis rates change during plant growth, frequently depending on variations in environmental factors (e.g., light and water) (LARCHER, 2010).

\section{Stomatal conductance}

The data obtained for stomatal conductance (Figure 3) showed initial values between 0.14 and $0.18 \mathrm{~mol} \mathrm{~m}^{-2} \mathrm{~s}^{-1}$ until day 11; afterward, these values varied from 0.04 to $0.12 \mathrm{~mol} \mathrm{~m}^{-2} \mathrm{~s}^{-1}$ until day 21 . On day $22,0.007 \mathrm{~mol} \mathrm{~m}^{-2} \mathrm{~s}^{-1}$ and day 23 , conductance was $0.0 \mathrm{~mol} \mathrm{~m}^{-2} \mathrm{~s}^{-1}$ with a hydric potential of -2.5 $\mathrm{MPa}$, and irrigation was then reinitiated. After 48 hours of irrigation, conductance rates were between 0.18 and $0.20 \mathrm{~mol} \mathrm{~m}^{-2} \mathrm{~s}^{-1}$ with a hydric potential of $0.5 \mathrm{MPa}$.

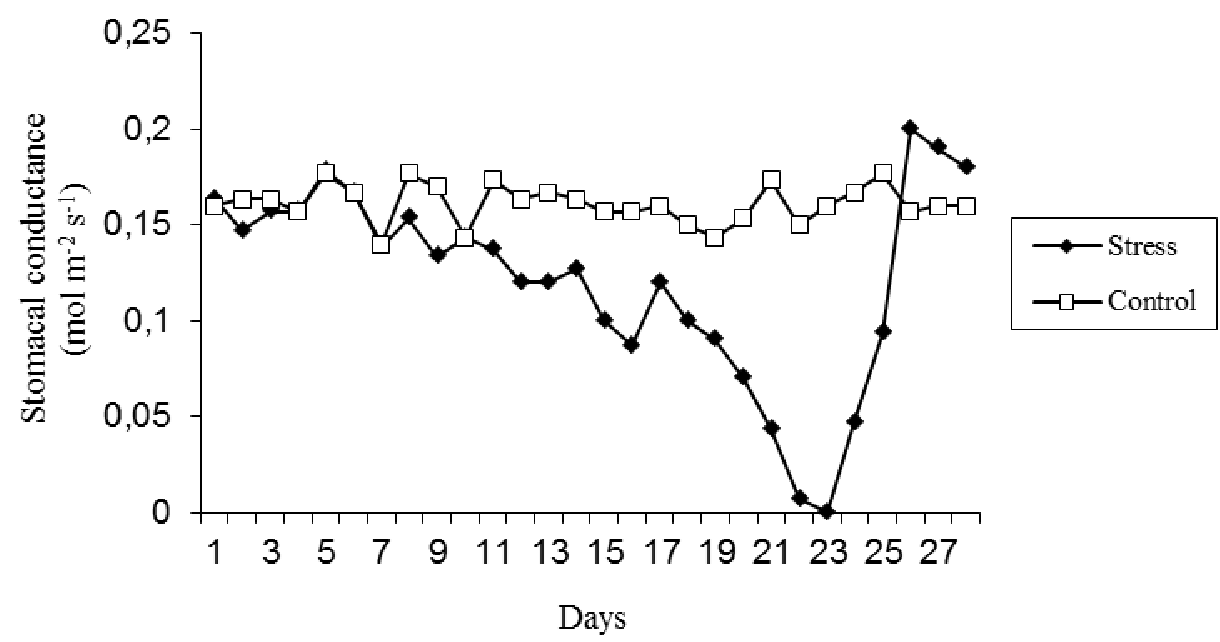

Figure 3. Stomatal conductance $\left(\mathrm{mol} \mathrm{m}^{-2} \mathrm{~s}^{-1}\right)$ in the two experimental groups (stress and control) of Tabebuia aurea potted plants.

These results (stomatal conductance) were expected, once an increase in hydric deficit always leads to either a reduction in conductance or an increase in stomatal resistance; however, this species had a fast recovery. With greater water deficits, there is more intense stomatal closure, which is important to maintain the integrity of the water transport system and a favorable hydric potential for leaflets development during the dry season or under conditions of water stress (AKINCI; LÖSEL, 2012).

Similar results to those found for Tabebuia aurea were reported by Rocha and Moraes (1997) who describe a decrease in conductance rates in $S$. adstringens under water stress; this species continually maintained its stomatal conductance rate between 0.10 and $0.32 \mathrm{~mol} \mathrm{~m}^{-2} \mathrm{~s}^{-1}$ until day 27, whose values reached zero on day 30 with a hydric potential of -2.7 MPa. After resuming irrigation, the conductance rate returned to the initial values within two days.

The same results were also demonstrated by Calbo and Moraes (2000) with decrease in conductance rates for the Amazonian species $E$. oleracea under stress, which initially varied from 0.05 to $0.12 \mathrm{~mol} \mathrm{~m}^{-2} \mathrm{~s}^{-1}$ during the first 24 days and decreased to zero on day 61 (hydric potential of -2.4 $\mathrm{MPa}$ ). On the other hand, the recovery of initial stomatal conductance rates was slow (14 days). Tatagiba et al. (2007) found that Eucaliptus clones, in which a decrease in conductance rates occurred during the dry season, increasing during the rainy season, and by Graça et al. (2010) for Saccharum spp. subjected to water deficit, but not all species may exhibit this behavior. Souza et al. (2010) studied four species under drought, and did not observe lower conductance rates in all these ones studied, except for Brosimum guianensis. 
Although Oliveira et al. (2011) found similar behavior for five-month-old $T$. aurea, with declining conductance rates during water stress, the lowest values were found after 14 days of stress. The data obtained for this experiment, with values of $0.0 \mathrm{~mol} \mathrm{~m}^{-2} \mathrm{~s}^{-1}$ after 22 days of stress once more indicate that as individuals become older, their ability to resist to water stress increases.

Galmés et al. (2007) investigated eight Mediterranean species subjected to water stress, and also reported a decrease in conductance by increasing the hydric failure, with a recovery of conductance rates after rehydration. This result was similar to that one reported by Silva et al. (2008) with Schinus terebinthifolius Raddi. According to Larcher (2010) and Akınci and Lösel (2012), some species can exhibit slow recovery of stomatal conductance due to the buildup of abscisic acid (ABA) during water stress with the recovery times varying according to the species. Regarding the species $T$. aurea, the rapid recovery observed could indicate low ABA buildup.

\section{Transpiration rates}

Transpiration rates varied from 2.0 to 2.6 $\mathrm{mmol} \mathrm{m} \mathrm{s}^{-2}$ until day 15 , and from 0.9 to $1.6 \mathrm{mmol}$ $\mathrm{m}^{-2} \mathrm{~s}^{-1}$ until day 21. On day 23, the lowest transpiration rate was observed $\left(0.0 \mathrm{mmol} \mathrm{m}^{-2} \mathrm{~s}^{-1}\right)$. After this point (day 23), irrigation was resumed, and the rates increased once again, returning to initial values at 96 hours after irrigation (Figure 4).

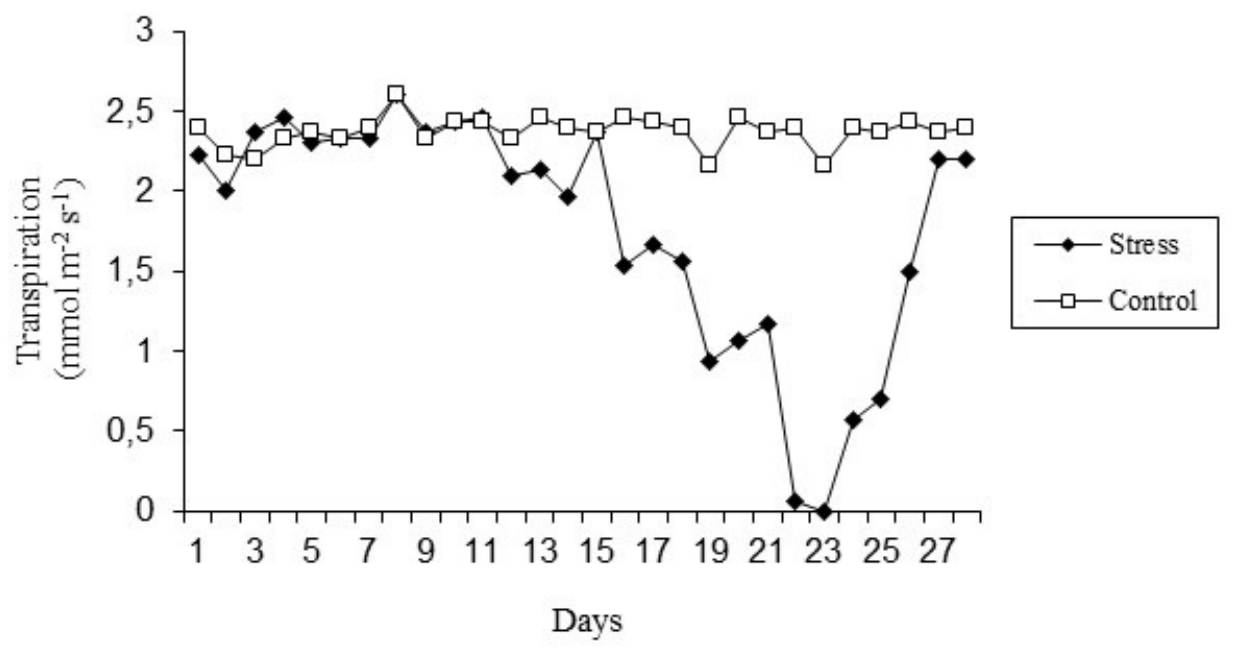

Figure 4. Transpiration rates $\left(\mathrm{mmol} \mathrm{m}^{-2} \mathrm{~s}^{-1}\right)$ in the two experimental groups (stress and control) of Tabebuia aurea potted plants.

According to Larcher (2010), when the soil has hydric excess (water saturation), higher transpiration rates occur and when the amount of water in the soil decreases; transpiration rates decrease via restriction mechanisms that prevent severe hydric reduction and plant death; transpiration rates can decrease with a continuous reduction in water until it reaches zero, which was observed for T. aurea. However, in a situation of water saturation, damage may occur to the root system under root oxygen stress, where the mitochondrial respiration is compromised while metabolism is shifted to fermentation (PEZESHKI; DELAUNE, 2012).

Although a decrease in water availability leads to an increase in water stress, expected for mesophytic species subjected to stress, adapted species can develop a resistance to this type of stress, and they are able to maintain transpiration for longer periods (LARCHER, 2010; RAHMAN; HASEGAWA, 2012). The rapid recovery (Figure 4) observed in the studied species indicates an adaptation to environments that are subjected to periodical stress.

We observed, in T. aurea, a correlation between the decrease in transpiration (Figure 4) and the reduction in stomatal conduction (Figure 3), demonstrating that cuticular transpiration is minimal during this growth stage, with the high cuticular resistance being an indication of drought tolerance.

However, the transpiration process in response to drought varies among plants. Rocha and Moraes (1997) reported that $S$. adstringens maintained high transpiration rates from 2.7 to 4.0 mmol m $\mathrm{m}^{-2} \mathrm{~s}^{-1}$ until day 26 , which decreased until 0.1 mmol m $\mathrm{m}^{-2} \mathrm{~s}^{-1}$ on day 30 , demonstrating a rapid drop 
in short time (3 days). After irrigation was resumed, transpiration returned to the initial values. Similar results were found by Oliveira et al. (2011) for fivemonth-old $T$. aurea; however, the lowest value was found after 15 days of stress, indicating once again a higher resistance to water stress as individuals of the species become older.

Adversely, Calbo and Moraes (2000) found that transpiration rates in E. oleracea under stress varied from 1.0 to $2.0 \mathrm{mmol} \mathrm{m} \mathrm{s}^{-1}$ during the first 30 days. After this first phase, the transpiration rates continued to decrease, reaching zero on day 61 ; the initial values returned after 14 days of irrigation.

Other studies also indicated a decrease in transpiration rates. As reported by Tatagiba et al. (2007), it was observed a decrease in transpiration rates during drought periods and an increase during rainy periods for Eucaliptus clones, while Silva et al. (2008) have reported a similar pattern for $S$.
OLIVEIRA, A. K. M.; GUALTIERI, S. C. J.

terebinthifolius, and Graça et al. (2010), for Saccharum spp. subjected to water deficit. However, not all species may exhibit this behavior. Souza et al. (2010) studied four species under drought, and did not observe lower transpiration rates in all species studied, except for B. guianensis.

\section{Photosynthesis rates}

Initial net photosynthesis rates varied from 8.1 to $9.5 \mu \mathrm{mol} \mathrm{m} \mathrm{m}^{-2} \mathrm{~s}^{-1}$ until day 15 when it dropped rapidly $\left(5.4 \mu \mathrm{mol} \mathrm{m}^{-2} \mathrm{~s}^{-1}\right.$ on day $19 ; 3.5 \mu \mathrm{mol} \mathrm{m}^{-2} \mathrm{~s}^{-1}$ on day 21) until reaching $0.0 \mu \mathrm{mol} \mathrm{m} \mathrm{m}^{-2} \mathrm{~s}^{-1}$ on day 23 with a hydric potential of $-2.6 \mathrm{MPa}$. At this point irrigation was resumed, and net photosynthesis rates were similar to the initial values after 72 hours of irrigation (Figure 5). Similarly, the hydric potential was also recovered $(-0.5 \mathrm{MPa})$, indicating that the leaflets mesophyll may not be affected during this period of stress.

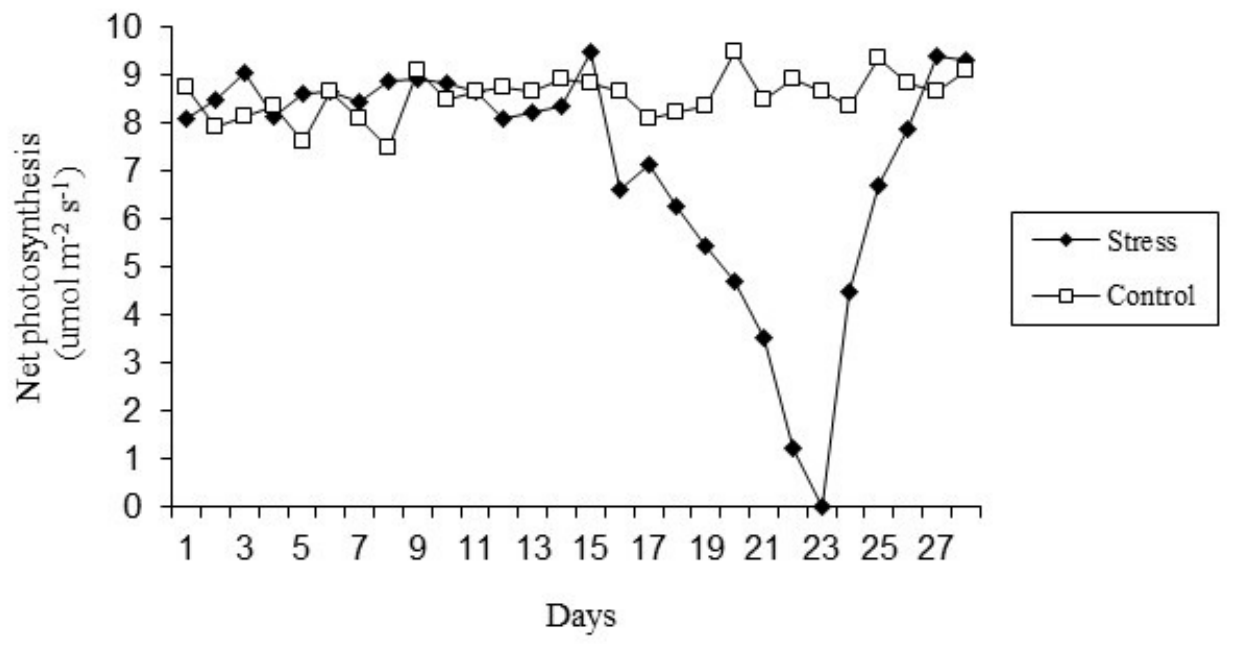

Figure 5. Photosynthesis rates $\left(\mu \mathrm{mol} \mathrm{m} \mathrm{m}^{-2}\right)$ in the two experimental groups (stress and control) of Tabebuia aurea potted plants.

According to Larcher (2010) and Rahman and Hasegawa (2012), reduction in photosynthesis rates is common in sensitive species, which is initially mediated by stomatal closing, and later by a reduction in photosynthetic capacity, what was reported by Rocha and Moraes (1997) with $S$. adstringens species, which maintained the photosynthesis rates between $8 \mu \mathrm{mol} \mathrm{m} \mathrm{m}^{-2} \mathrm{~s}^{-1}$ and $11.6 \mu \mathrm{mol} \mathrm{m} \mathrm{m}^{-2} \mathrm{~s}^{-1}$ until day 25 of water stress. Then, these values dropped on day $27\left(3.8 \mu \mathrm{mol} \mathrm{m} \mathrm{m}^{-2} \mathrm{~s}^{-1}\right)$ until reaching zero on day 30 with total recovery occurring after 48 hours of irrigation.

Similar results were found by Oliveira et al. (2011) for five-month-old T. aurea, but the lowest value was found after 14 days of stress, one more time indicating higher resistance to water stress as individuals of the species become older. Tatagiba et al. (2007) also observed a decrease in Eucaliptus photosynthesis rates during the dry season, and an increase during the rainy period, and by Graça et al. (2010) with Saccharum spp. subjected to water deficit.

However, not all species may exhibit this behavior. Souza et al. (2010) studied four species under drought, and did not observe lower photosynthesis rates in all species studied, except for B. guianensis.

Cornic (2000) and Rahman and Hasegawa (2012) wrote that hydric restriction normally causes in parallel a decrease in photosynthesis and 
Gas exchange in young plants...

conductance rates; this occurs due to the absorption capacity of the mesophyll (conductance) that changes in leaves submitted to drought due to stomatal closing.

According to Larcher (2010), the photosynthetic rates decrease with the reduction in hydric potential of leaflets. However, the point where the restriction began to affect photosynthesis rates was variable from species to species due to genotype, environmental conditions, and history of each plant. Adversely, the time interval between rehydration and plant physiological response can vary according to plant species and water deficit imposed (SOUZA et al., 2004; LIBERATO et al., 2006).

According to Oliveira et al. (2011), the arborea species $T$. aurea has the ability to survive during drought periods without any loss in photosynthetic capability, and this resistance increases as individuals become older. This
OLIVEIRA, A. K. M.; GUALTIERI, S. C. J.

adaptation is connected to a reduction in stomatal opening that leads to a reduction in transpiration rates and, consequently, in photosynthesis.

To conclude, T. aurea has mechanisms to tolerate temporary hydric deficits, which may be considered ecologically relevant, with reduction of transpiration rates, stomatal conductance, and net photosynthesis due to the increased time of stress. After the end of the stress, the rates return to normal values, indicating recovery of the parameters evaluated.

\section{ACKNOWLEDGEMENTS}

We would like to thank $\mathrm{CNPq}$ for granting scholarships to both authors. We are indebted to Anhanguera-Uniderp University, which supported this work (Interdisciplinary Group of Research GIP Project).

RESUMO: O paratudo, Tabebuia aurea, é uma árvore comumente encontrada no Pantanal de Miranda, Mato Grosso do Sul, uma área com sazonalidade hídrica. Para avaliar o efeito do estresse hídrico sobre as trocas gasosas de $\mathrm{CO}_{2}$, plantas com 10 meses de idade de T. aurea cultivadas em sacos de plantio foram submetidas a estresse hídrico através da supressão de irrigação por 23 dias. Condutância estomática, transpiração e fotossíntese líquida foram medidas durante o período de estresse e recuperação, totalizando 28 dias, com um analisador portátil de gás infravermelho. Depois de 23 dias sem irrigação, as taxas de transpiração, condutância e fotossíntese nas folhas chegaram a zero, enquanto o potencial hídrico das folhas, -2.6 MPa. Depois deste ponto, a irrigação foi retomada e os valores médios das variáveis avaliadas, depois de $96 \mathrm{~h}$, voltaram aos valores iniciais (taxa de transpiração entre 2.0 e $2.6 \mathrm{mmol} \mathrm{m}^{-2} \mathrm{~s}^{-1}$; taxa de condutância estomática entre 0.12 e $0.18 \mathrm{~mol} \mathrm{~m} \mathrm{~m}^{-1}$ e taxa fotossintética entre 8.1 e $9.5 \mu \mathrm{mol} \mathrm{m} \mathrm{m}^{-1}$ ). O potencial hídrico também retornou aos valores do início do experimento (-0.5 MPa). Os resultados demonstraram que T. aurea possui tolerância a períodos de seca, permitindo sua sobrevivência em áreas sujeitas a estresse hídrico periódico.

PALAVRAS-CHAVE: Déficit hídrico. Fotossíntese. Condutância estomática. Paratudo.

\section{REFERENCES}

AKINCI, S.; LÖSEL, D. M. Plant water-stress response mechanisms. In: RAHMAN, I. M. M.; HASEGAWA, H. (Edts). Water stress. Publisher: InTech, 2012. p. 15-42.

CALBO, M. E. R.; MORAES, J. A. P. V. Efeitos da deficiência de água em plantas de Euterpe oleracea (açaí). Revista Brasileira de Botânica, São Paulo, v. 23, n. 3, p. 225-230, 2000. https://doi.org/10.1590/s010084042000000300001

CHAVES, M. M.; PEREIRA, J. S.; MAROCO, J.; RODRIGUES, M. L.; RICARDO, C. P. P.; OSORIO, M. L.; CARVALHO, I.; FARIA, T.; PINHEIRO, C. How plants cope with water stress in the field? Photosynthesis and growth. Annals Botany, Oxford, v. 89, n. 7, p. 907-916, 2002. https://doi.org/10.1093/aob/mcf105

CORNIC, G. Drought stress inhibits photosynthesis by decresing stomatal aperture - not by affecting ATP synthesis. Trends in Plant Science, Amsterdam, v. 5, n. 5, p. 187-188, 2000. https://doi.org/10.1016/S13601385(00)01625-3 
FRANCO, A. C.; BUSTAMANTE, M.; CALDAS, L. S.; GOLDSTEIN, G.; MEINZER, F. C.; KOZOVITS, A. R.; RUNDEL, P.; CORADINI, V. T. R. Leaf functional traits of Neotropical savanna trees in relation to seasonal water deficit: from wet to dry: tropical trees in relation to water availability. Trees - Structure and Function, New York, v. 19, n. 3, p. 326-335, 2005.

GALLÉ. A.; HALDIMANN, P.; FELLER, U. Photosynthetic performance and water relations in young pubescent oak (Quercus pubescens) trees during drought stress and recovery. New Phytologist, Lancaster, v. 174, n. 4, p. 799-810, 2007. https://doi.org/10.1111/j.1469-8137.2007.02047.x

GALMÉS, J.; MEDRANO, H.; FLEXAS, J. Photosynthetic limitations in response to water stress and recovery in Mediterranean plants with different growth forms. New Phytologist, Oxford, v. 175, n. 1, p. 81-93, 2007. https://doi.org/10.1111/j.1469-8137.2007.02087.x

GRAÇA, J. P.; RODRIGUES, F. A.; FARIAS, J. R. B.; OLIVEIRA, M. C. N.; HOFFAMANN-CAMPO, C. B.; ZINGARETTI, S. M. Physiological parameters in sugarcane cultivars submitted water deficit. Brazilian Journal of Plant Physiology, Piracicaba, v. 22, n. 3, p. 189-197, 2010. https://doi.org/10.1590/S167704202010000300006

JALEEL, C. A.; MANIVANNAN, P.; WAHID, A.; FAROOQ, M.; AL-JUBURI, H. J.; SOMASUNDARAM, R.; PANNEERSELVAM, R. Drought stress in plants: a review on morphological characteristics and pigments composition. International Journal Agricultural Biology, Pakistan, v. 11, n. 1, p. 100-105, 2009.

LARCHER, W. Physiological plant ecology: ecophysiology and stress physiology of functional groups. $4^{\text {th }}$ ed. New Delhi: Springer, 2010. 513p.

LAWLOR, D. W.; CORNIC, G. Photosynthetic carbon assimilation and associated metabolism in relation to water deficits in higher plants. Plant, Cell and Environment, Oxford, v. 25, n. 2, p. 275-294, 2002. https://doi.org/10.1046/j.0016-8025.2001.00814.x

LIBERATO, M. A. R.; GONÇALVES, J. F. C.; CHEVREUIL, L. R.; NINA JUNIOR, A. R.; FERNANDES, A. V.; SANTOS JUNIOR. U. M. Leaf water potential, gas exchange and chlorophyll a fluorescence in acariquara seedlings (Minquartia guianensis Aubl.) under water stress and recovery. Brazilian Journal of Plant Physiology, Londrina, v. 18, n. 2, p. 315-323, 2006.

MANSUR, R. J. C. N.; BARBOSA, D. C. A. Comportamento fisiológico em plantas jovens de quatro espécies lenhosas da caatinga submetidas a dois ciclos de estresse hídrico. Phyton, Buenos Aires, n. 68, p. 97-106, 2000.

MARTINEZ, J. P.; SILVA, H.; LEDENT, J. F.; PINTO, M. Effect of drought stress on the osmotic adjustment, cell wall elasticity and cell volume of six cultivars of common beans (Phaseolus vulgaris L.). European Journal of Agronomy, ScienceDirect, v. 26, n. 1, p. 30-38, 2007.

MÉNDEZ, Y. D. R.; CHACÓN, L. M.; BAYONA, C. J.; ROMERO, H. M. Physiological response of oil palm interspecific hybrids (Elaeis oleifera H.B.K. Cortes versus Elaeis guineensis Jacq.) to water deficit. Brazilian Journal of Plant Physiology, Campo dos Goytacazes, v. 24, n. 4, p. 273-280, 2012.

MORAIS, H.; MARUR, C. J.; CARAMORI, P. H.; RIBEIRO, A. M. A.; GOMES, J. C. Características fisiológicas e de crescimento de cafeeiro sombreado com guandu e cultivado a pleno sol. Pesquisa Agropecuária Brasileira, Brasília, v. 38, n. 10, p. 35-40, 2003. https://doi.org/10.1590/S0100204X2003001000001

MOTA, C. S.; AMARANTE, C. V. T.; SANTOS, H. P.; ALBUQUERQUE, J. A. Disponibilidade hídrica, radiação solar e fotossíntese em videiras 'Cabernet Sauvignon' sob cultivo protegido. Revista Brasileira de Fruticultura, Jaboticabal, v. 31, n. 2, p. 432-439, 2009. 
OLIVEIRA, A. B.; ALENCAR, N. L. M.; GOMES-FILHO, E. Physiological and biochemical responses of semiarid plants subjected to water stress. In: RAHMAN, I. M. M.; HASEGAWA, H. (Eds). Water stress. Publisher: InTech, 2012. p. 43-58. https://doi.org/10.5772/29444

OLIVEIRA, A. K. M.; GUALTIERI, S. C. J.; BOCCHESE, R. A. Gas exchange of potted Tabebuia aurea plants under hydric stress. Acta Scientiarum Agronomy, Londrina, v. 33, n. 4, p. 641-647, 2011. https://doi.org/10.4025/actasciagron.v33i4.11254

PEZESHKI, S. R.; DELAUNE, R. D. Soil oxidation-reduction in wetlands and its impact on plant functioning. Biology, Basel, v. 1, n. 2, p. 196-221, 2012. https://doi.org/10.3390/biology1020196

RAHMAN, I. M. M.; HASEGAWA, H. Water stress. Publisher: InTech, 2012. 300p. https://doi.org/10.5772/1419

ROCHA, M. A. S.; MORAES, J. A. P. V. Influência do estresse hídrico sobre as trocas gasosas em plantas jovens envasadas de Stryphnodendron adstringens (Mart.) Coville. Revista Brasileira de Fisiologia Vegetal, Brasília, v. 9, n. 1, p. 43-48, 1997.

SAITO, T.; TERASHIMA, I. Reversible decreases in the bulk elastic modulus of mature leaves of deciduous Quercus species subjected to two drought treatments. Plant, Cell and Environment, London, v. 27, n. 2, p. 863-875, 2004. https://doi.org/10.1111/j.1365-3040.2004.01192.x

SCREMIN-DIA, E.; LORENZ-LENKE, A. P.; OLIVEIRA, A. K. M. The floristic heterogeneity of the Pantanal and the occurrence of species with different adaptive strategies to water stress. Brazilian Journal of Biology, São Carlos, v. 71, n. 1, p. 275-282, 2011. https://doi.org/10.1590/S1519-69842011000200006

SILVA, M. A. V.; NOGUEIRA, R. J. M. C.; OLIVEIRA, A. F. M.; SANTOS, V. F. Resposta estomática e produção de matéria seca em plantas jovens de aroeira submetidas a diferentes regimes hídricos. Revista Árvore, Viçosa, v. 32, n. 2, p. 335-344, 2008.

SOARES, J. J.; OLIVEIRA, A. K. M. Os paratudais no Pantanal de Miranda. Revista Árvore, Viçosa, v. 33, n. 2, p. 339-347, 2009.

SOUZA, R. P.; MACHADO, E. C.; SILVA, J. A. B.; LAGÔA, A. M. M. A.; SILVEIRA, J. A. G. Photosynthetic gas exchange in cowpea (Vigna unguiculata) during water stress and recovery. Environmental and Experimental Botany, Elsevier, v. 51, n. 1, p. 45-56, 2004. https://doi.org/10.1016/S00988472(03)00059-5

SOUZA, B. D.; RODRIGUES, B. M.; ENDRES, L.; SANTO, M. G. Ecophysiolgy parameters of four Brazilian Atlantic Forest species under shade and drought stress. Acta Physiologia Plantarum, Heidelberg, v.32, n.4, p.729-737, 2010. https://doi.org/10.1007/s11738-009-0454-5

TATAGIBA, S. D.; PEZZOPANE, J. E. M.; REIS, E. F.; DARDENGO, M. C. J. D.; EFFGEN, T. A. M. Comportamento fisiológico de dois clones de Eucalyptus na época de seca e chuvosa. Cerne, Lavras, v. 3, n. 2, p. 149-159, 2007.

TAIZ, L.; ZEIGER, E. Plant physiology. $5^{\text {th }}$ ed. Sunderland: Sinauer Associates, 2010. 690p.

WANG, R.; HUANG, W.; CHEN, L.; MA, L.; GUO, C.; LIU, X. Anatomical and physiological plasticity in Leymus chinensis (Poaceae) along large-scale longitudinal gradient in Northeast China. PLoS ONE, São Francisco, v.6, n.11,e26209, 2011.

XU, Z.; ZHOU, G. Responses of leaf stomatal density to water status and its relationship with photosynthesis in a grass. Jornal of Experimental Botany, v. 56, n. 12, p. 3317-3325, 2008. https://doi.org/10.1093/jxb/ern185 